\title{
UJI EFEKTIVITAS PUPUK ORGANONITROFOS DAN KOMBINASINYA DENGAN PUPUK ANORGANIK TERHADAP PERTUMBUHAN, SERAPAN HARA DAN PRODUKSI TANAMAN MENTIMUN (Cucumis sativus L.) PADA MUSIM TANAM KEDUA DI TANAH ULTISOL GEDUNG MENENG
}

\author{
Agung Ade Wijaya, Jamalam Lumbanraja \& Yohanes C. Ginting \\ Jurusan Agroteknologi Fakultas Pertanian Universitas \\ Lampung, Jl. Prof. Soemantri Brodjonegoro No. 1 Bandarlampung 35143 \\ E-mail: agungade24@gmail.com
}

\begin{abstract}
ABSTRAK
Pupuk Organonitrofos yang merupakan salah satu jenis pupuk organik yang mampu menyediakan unsur hara berimbang, khususnya $\mathrm{N}$ dan $\mathrm{P}$ berasal dari proses pengomposan kotoran sapi dan batuan fosfat yang ditambahkan mikroba pelarut fosfat dan mikroba penambat nitrogen. Penelitian ini bertujuan untuk: (1) Menyelidiki pengaruh pemberian pupuk organonitrofos dan kombinasinya dengan pupuk anorganik terhadap pertumbuhan, serapan hara dan produksi pada tanaman mentimun, (2) Menetapkan kombinasi pupuk organonitrofos dengan pupuk anorganik yang paling efektif secara agronomis maupun ekonomis pada tanaman mentimun. Penelitian ini terdiri dari 6 perlakuan dengan 3 ulangan disusun dalam Rancangan Acak kelompok

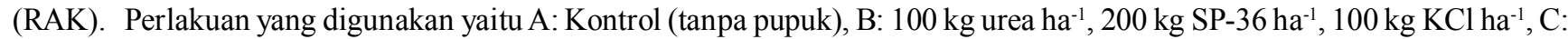

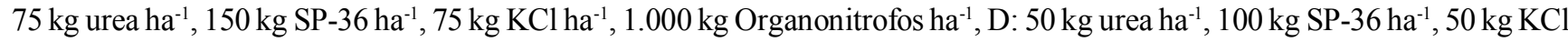

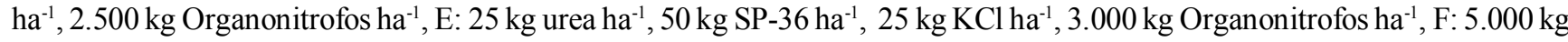
Organonitrofos ha ${ }^{-1}$. Variabel pengamatan meliputi panjang tanaman, jumlah cabang, jumlah bunga betina, jumlah bunga jantan, jumlah bunga betina jadi buah, jumlah buah per pohon, bobot berangkasan segar, bobot berangkasan kering, bobot buah, bobot rata-rata buah, analisis tanah, dan analisis tanaman. Data dianalisis dengan analisis ragam dan perbedaan nilai tengah perlakuan dengan uji Beda Nyata Terkecil (BNT) pada taraf nyata 5\%. Hasil penelitian menunjukkan bahwa pemberian

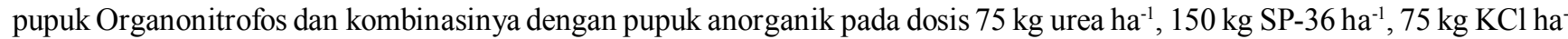
${ }^{1}, 1.000 \mathrm{~kg}$ Organonitrofos ha ${ }^{-1}$ dapat meningkatkan serapan hara $\mathrm{N}, \mathrm{P}, \mathrm{K}$, namun tidak berpengaruh terhadap pertumbuhan dan produksi mentimun pada musim tanam kedua. Pupuk tunggal Organonitrofos dosis $5.000 \mathrm{~kg} \mathrm{ha}^{-1}$ lebih direkomendasikan untuk petani mentimun, karena merupakan dosis paling efektif secara agronomis (Relative Agronomic Effektiviness) maupun secara ekonomis dan dapat menciptakan pertanian yang berkelanjutan.
\end{abstract}

Kata Kunci : kombinasi, mentimun, organonitrofos, pupuk

\section{PENDAHULUAN}

Mentimun merupakan suatu jenis sayuran dari keluarga labu-labuan (Cucurbitacae) yang sudah popular di seluruh dunia. Menurut BPS (2013), produksi mentimun di Indonesia pada tahun terakhir mengalami penurunan. Pada tahun 2011 dengan luas lahan 53,596 ha jumlah produksi mentimun mencapai 521,535 ton, sedangkan dengan luas yang sama pada tahun 2012 produksi mentimun hanya mencapai 512,556 ton. Produksi rata-rata masih jauh di bawah potensi tanaman itu sendiri yaitu $9,7 \mathrm{t} \mathrm{ha}^{-1}$ pada tahun 2011 dan $9,5 \mathrm{tha}^{-1}$ pada tahun 2012. Sedangkan petani mentimun seharusnya bisa mencapai $30-40 \mathrm{t} \mathrm{ha}^{-1}$. Seiring dengan meningkatnya jumlah penduduk dan berkembangannya industri pangan, maka permintaan mentimun terus meningkat baik kebutuhan rumah tangga maupun industri pangan.

Tanah Ultisol di Indonesia sangat besar mengingat luas tanah ultisol sekitar mencapai 45,794,000 ha atau sekitar 25\% dari total luas daratan Indonesia (Subagyo dkk., 2004). Pada umumnya tanah ini mempunyai potensi keracunan $\mathrm{Al}$ dan miskin kandungan bahan organik. Tanah ini juga miskin kandungan hara terutama $\mathrm{P}$ dan kation-kation dapat ditukar seperti $\mathrm{Ca}, \mathrm{Mg}, \mathrm{Na}$, dan K, kadar Al tinggi, kapasitas tukar kation rendah, dan peka terhadap erosi (Sri Adiningsih dan Mulyadi, 1993).

Salah satu upaya yang dapat meningkatkan produktivitas tanah adalah dengan pemberian pupuk yang cukup agar pertumbuhan dan produksi tanaman mentimun dapat ditingkatkan. Untuk memenuhi 
kebutuhan hara bagi tanaman maka pupuk dapat diberikan, baik pupuk organik maupun pupuk anorganik. Akhir-akhir ini, petani skala kecil sangat sulit untuk mendapatkan pupuk anorganik tersebut di pasaran dikarenakan kondisinya yang langka dan harganya yang melambung tinggi (Agromedia, 2010). Di sisi lain Sutedjo (1994), menyatakan bahwa penggunaan pupuk anorganik yang berlebihan dan secara terus-menerus dapat mengakibatkan kesuburan tanah menjadi berkurang dan tanah menjadi keras, menimbulkan polusi lingkungan serta penurunan kualitas lahan. Hal ini perlu disiasati dengan cara mengurangi penggunaan pupuk anorganik dengan menggunakan pupuk organik yang harganya lebih murah dan ramah lingkungan (Syukur, 2005).

Salah satu jenis pupuk organik yang mampu menyediakan unsur hara $\mathrm{N}$ dan $\mathrm{P}$ yang cukup tinggi yaitu pupuk organik organomineral NP (organonitrofos) yang dirancang oleh tim dosen Fakultas Pertanian Universitas Lampung. Pupuk organonitrofos merupakan salah satu bentuk pupuk organik yang berasal dari 70-80\% kotoran sapi dan $20-30 \%$ batuan fosfat, dengan penambahan mikroba penambat $\mathrm{N}$ dan pelarut $\mathrm{P}$ (Nugroho dkk., 2012). Dengan pemberian pupuk organonitrofos ini diharapkan dapat meningkatkan pertumbuhan dan produksi tanaman mentimun sehingga mampu menciptakan kegiatan pertanian yang berkelanjutan dan ramah lingkungan. Oleh karena itu, penelitian ini dilakukan untuk mengetahui pengaruh pupuk organonitrofos dan kombinasinya dengan pupuk anorganik terhadap pertumbuhan, serapan hara dan produksi tanaman mentimun pada musim tanam kedua di tanah ultisol Gedung Meneng.

Penelitian ini bertujuan untuk menyelidiki pengaruh pemberian pupuk organonitrofos dan kombinasinya dengan pupuk anorganik serta menetapkan kombinasi pupuk organonitrofos dengan pupuk anorganik yang paling efektif secara agronomis maupun ekonomis pada tanaman mentimun.

\section{BAHAN DAN METODE}

Penelitian ini dilakukan di Laboratorium Lapang Terpadu Fakultas Pertanian Universitas Lampung dan Laboratorium Kimia Tanah Fakultas Pertanian Universitas Lampung. Penelitian dilakukan pada bulan Agustus 2013 sampai November 2013.

Penelitian ini terdiri dari 6 perlakuan dengan 3 ulangan disusun dalam Rancangan Acak Kelompok (RAK). Homogenitas ragam diuji dengan uji Bartlet, adiktivitas data diuji dengan uji Tukey. Jika asumsi terpenuhi data dianalisis dengan sidik ragam, perbedaan nilai tengah perlakuan diuji denga uji Beda Nyata Terkecil (BNT) pada taraf 5\%. Daftar perlakuan A: Kontrol (tanpa pupuk), B: $100 \mathrm{~kg}$ urea ha-1, $200 \mathrm{~kg} \mathrm{SP}-36 \mathrm{ha}^{-1}$, $100 \mathrm{~kg} \mathrm{KCl} \mathrm{ha}{ }^{-1}$, C: $75 \mathrm{~kg}$ urea ha-1, $150 \mathrm{~kg} \mathrm{SP-36} \mathrm{ha-1,}$ $75 \mathrm{~kg} \mathrm{KCl} \mathrm{ha}^{-1}, 1.000 \mathrm{~kg}$ Organonitrofos ha ${ }^{-1}$, D: $50 \mathrm{~kg}$ urea ha-1, $100 \mathrm{~kg} \mathrm{SP}^{-36} \mathrm{ha}^{-1}, 50 \mathrm{~kg} \mathrm{KCl} \mathrm{ha}{ }^{-1}, 2.500 \mathrm{~kg}$ Organonitrofos ha- ${ }^{-1}$, E: $25 \mathrm{~kg}$ urea ha ${ }^{-1}, 50 \mathrm{~kg} \mathrm{SP}-36$ $\mathrm{ha}^{-1}, 25 \mathrm{~kg} \mathrm{KCl} \mathrm{ha}{ }^{-1}, 3.000 \mathrm{~kg}$ Organonitrofos ha- ${ }^{-1}, \mathrm{~F}$ : $5.000 \mathrm{~kg}$ Organonitrofos ha ${ }^{-1}$.

Petak percobaan masing-masing dibuat sebanyak 6 petak percobaan dengan 3 ulangan. Masing-masing petak berukuran $3 \times 3 \mathrm{~m}$ jarak antarpetak $30 \mathrm{~cm}$ dan jarak tanam 40x $70 \mathrm{~cm}$. Pengolahan tanah dilakukan dengan beberapa tahap meliputi : pembersihan lahan, penggemburan, dan pembuatan bedengan. Setelah 7 HST dilakukan pemasangan ajir.

Aplikasi pupuk dilakukan sebanyak dua kali. Pertama aplikasi pupuk urea dengan dosis setengah dosis dilakukan setelah tanah siap ditanam bersamaan dengan pupuk organonitrofos, SP - 36 dan $\mathrm{KCl}$. Kedua aplikasi pupuk urea dengan dosis setengah dosis dilakukan saat bunga muncul.

Pengambilan sampel tanah dilakukan sebanyak dua kali, yaitu pertama pengambilan pada waktu sebelum masa tanam dan kedua pengambilan sampel setelah pemanenan buah mentimun. Variabel yang diamati pada penelitian ini meliputi panjang tanaman, jumlah cabang, jumlah bunga betina, jumlah bunga jantan, jumlah bunga betina jadi buah, jumlah buah per pohon, bobot berangkasan segar, bobot berangkasan kering, bobot buah segar, bobot rata-rata buah.

Analisis tanah dilakukan setelah panen dengan cara pengambilan sampel tanah untuk di analisis N-total menggunakan metode Kjechdahl, P-tersedia menggunakan metode Bray, Kdd, $\mathrm{pH}$ tanah, dan $\mathrm{C}$ organik menggunakan metode Walkey and Black. Analisis tanaman dilakukan setelah panen dengan cara menganalisis $\mathrm{N}, \mathrm{P}$, dan $\mathrm{K}$ pada sample tanaman, baik berangkasan maupun buah yang sudah di oven.

Efektivitas agronomi pupuk ditentukan dengan metode Relative Agronomic Effectiveness (RAE) dengan rumus sebagai berikut (Machay dkk., 1984) :

$R A E=\frac{\text { Hasil pupuk yang diuji }- \text { Kontrol }}{\text { Hasil pupuk standar }- \text { Kontrol }} \times 100 \%$

Keterangan :

Nilai $\mathrm{RAE} \geq 100 \%$ maka pupuk yang diuji efektif dibandingkan perlakuan standar. 
Uji efektivitas ekonomis pupuk digunakan untuk mengetahui apakah pupuk yang digunakan memiliki nilai ekonomis yang baik. Jika nilai yang dihasilkan lebih dari satu maka pupuk yang diuji tersebut memiliki nilai ekonomis baik (Saeri dan Suwono, 2012).

Efektivitas ekonomis pupuk $=\frac{P \times Q}{C}$

Keterangan :

$\mathrm{P}=$ Harga mentimun $\mathrm{Rp} \mathrm{kg}^{-1}$.

$\mathrm{Q}=$ Bobot segar buah mentimun $\mathrm{kg} \mathrm{ha}^{-1}$.

$\mathrm{C}=$ Biaya pengeluaran untuk pembelian pupuk $\mathrm{Rp} \mathrm{ha}^{-1}$

Nilai rasio $>1$ maka pupuk yang diuji memiliki nilai ekonomis yang menguntungkan.

Uji korelasi dilakukan untuk melihat korelasi antara serapan hara N, P, dan K terhadap tinggi tanaman pengamatan terakhir, cabang tanaman, bobot buah mentimun, dan bobot berangkasan tanaman.

\section{HASIL DAN PEMBAHASAN}

Pupuk Organonitrofos merupakan formulasi pupuk organik dari bahan organik berupa fermentasi kotoran sapi segar (fresh manure) dan batuan fosfat (rock phosphate) yang ditambahkan mikroorganisme penambat $\mathrm{N}\left(\mathrm{N}_{2}\right.$ fixer $)$ dan pelarut $\mathrm{P}$ (P-solubilizer) (Nugroho dkk., 2012).

Berdasarkan hasil analisis sifat kimia, pupuk Organonitrofos menunjukkan bahwa pupuk ini belum sesuai dengan syarat minimal pupuk organik yang ditetapkan oleh SNI (Tabel 1). Oleh karena itu perlu adanya reformulasi dengan menggunakan bahan baku yang memiliki kandungan hara lebih tinggi agar kandungan pupuk Organonitrofos dapat meningkat dan sesuai dengan kriteria syarat minimal pupuk organik berdasarkan SNI.

Hasil analisis kimia tanah awal (pada akhir musim tanam pertama) dan hasil analisis kimia tanah akhir setelah aplikasi pupuk Organonitrofos dan kombinasinya dengan pupuk anorganik (pada akhir musim tanam kedua). Pada musim tanam kedua yang ditanami mentimun, kandungan N-total tanah dan C-Organik menurun, baik yang diberi pupuk tunggal Organonitrofos maupun kombinasi dengan pupuk anorganik (Tabel $2 \& 3$ ). Hal ini di duga karena kandungan $\mathrm{N}$ dalam tanah banyak yang menguap karena cuaca sangat kering dan panas.

Kadar P-tersedia pada musim tanam kedua juga menurun, baik yang diberi pupuk tunggal Organonitrofos maupun kombinasi dengan pupuk anorganik (Tabel 3). Hal ini diduga karena kandungan $P$ pada tanah banyak yang diserap oleh tanaman dalam proses pertumbuhan tanaman mentimun. Menurut Simanungkalit (2006), unsur fosfat $(\mathrm{P})$ adalah unsur essensial kedua setelah $\mathrm{N}$ yang berperan penting dalam fotosintesis dan perkembangan akar.

Kadar K-dd tanah juga meningkat, terlihat pada perlakuan B (100 kg urea ha- ${ }^{-1}, 200 \mathrm{~kg} \mathrm{SP-36} \mathrm{ha-1}, 100$ $\mathrm{kg} \mathrm{KCl} \mathrm{ha}{ }^{-1}$ ) (Tabel 4). Hal ini diduga karena pengaruh pemberian pupuk anorganik secara langsung khususnya $\mathrm{KCl}$ dengan dosis tinggi. Wargiono (2003), menyatakan pemupukan $\mathrm{K}$ dengan takaran tinggi dapat meningkatkan ketersediaan $\mathrm{K}$ dalam tanah. Selain itu hal ini juga disebabkan oleh meningkatnya $\mathrm{pH}$ tanah (Tabel 3) sehingga berpengaruh terhadap ketersediaan unsur hara $\mathrm{Ca}, \mathrm{Mg}, \mathrm{P}$ dan K (Salam, 2012).

Pemberian pupuk Organonitrofos juga mampu memperbaiki $\mathrm{pH}$ tanah. Nilai $\mathrm{pH}$ pupuk anorganik tunggal dan pupuk anorganik yang dikombinasikan dengan pupuk Organonitrofos tidak terdapat perbedaan yang signifikan antara musim tanam pertama dan musim tanam kedua.

Peningkatan pertumbuhan dapat dilihat pada (Gambar 1) dan (Gambar 2). Pada (Gambar 1) dapat dilihat peningkatan panjang tanaman pada setiap minggunya sedangkan (Gambar 2) peningkatan cabang tanaman. Dari hasil anara menunjukkan bahwa pemberian pupuk Organonitrofos dan kombinasinya dengan pupuk anorganik tidak berpengaruh nyata terhadap panjang tanaman dan cabang tanaman

Tabel 1. Hasil analisis sifat kimia pupuk Organonitrofos.

\begin{tabular}{lcc}
\hline \multicolumn{1}{c}{ Analisis } & Sifat kimia pupuk Organonitrofos & $\begin{array}{c}\text { Syarat minimal pupuk organik } \\
\text { berdasarkan SNI(*) }\end{array}$ \\
\hline $\mathrm{pH}\left(\mathrm{H}_{2} \mathrm{O}\right)$ & 7,63 & $4-9$ \\
C-organik (\%) & 3,32 & $\min 15$ \\
N-total (\%) & 0,28 & $\min 4$ \\
P-total (\%) & 3,40 & $\min 4$ \\
K-total (\%) & 0,43 & $\min 4$ \\
\hline
\end{tabular}

(*) Sumber syarat minimal pupuk organik berdasakan SNI : (Permentan, 2011). 
Tabel 2. Hasil analisis kimia tanah awal (pada akhir musim tanam pertama) dan hasil analisis kimia tanah akhir setelah aplikasi pupuk Organonitrofos dan kombinasinya dengan pupuk anorganik (pada akhir musim tanam kedua).

\begin{tabular}{|c|c|c|c|c|c|c|c|}
\hline \multirow{2}{*}{\multicolumn{2}{|c|}{ Jenis Analisis }} & \multicolumn{6}{|c|}{ Perlakuan $\left(\mathrm{kg} \mathrm{ha}^{-1}\right)$} \\
\hline & & \multirow{2}{*}{$\frac{\mathrm{A}}{0,11(\mathrm{R})}$} & \multirow{2}{*}{$\frac{B}{0,66(T)}$} & \multirow{2}{*}{$\frac{C}{0,25(S)}$} & \multirow{2}{*}{$\frac{\mathrm{D}}{0,22(\mathrm{~S})}$} & \multirow{2}{*}{$\frac{E}{0,13(R)}$} & \multirow{2}{*}{$\frac{F}{0,16(\mathrm{R})}$} \\
\hline N-Total & Awal & & & & & & \\
\hline$(\%)$ & Akhir & $0,13(\mathrm{R})$ & $0,19(\mathrm{R})$ & $0,22(\mathrm{~S})$ & $0,19(\mathrm{R})$ & $0,16(\mathrm{R})$ & $0,13(\mathrm{R})$ \\
\hline \multirow{2}{*}{$\begin{array}{l}\text { P-Tersedia } \\
\quad(\mathrm{ppm})\end{array}$} & Awal & $3,91(\mathrm{R})$ & $5,68(\mathrm{R})$ & $5,25(\mathrm{R})$ & $7,78(\mathrm{~S})$ & $7,78(\mathrm{~S})$ & $11,6(\mathrm{~T})$ \\
\hline & Akhir & $5,35(\mathrm{R})$ & $6,25(\mathrm{R})$ & $6,13(\mathrm{R})$ & $5,44(\mathrm{R})$ & $5,81(\mathrm{R})$ & $7,17(\mathrm{R})$ \\
\hline \multirow{2}{*}{$\begin{array}{c}\text { K-dd } \\
\text { (me } 100 \mathrm{~g}-1)\end{array}$} & Awal & $0,50(\mathrm{~S})$ & $0,55(\mathrm{~S})$ & $0,56(\mathrm{~S})$ & $0,66(\mathrm{~T})$ & $0,68(\mathrm{~T})$ & $0,57(\mathrm{~S})$ \\
\hline & Akhir & $0,59(\mathrm{~S})$ & $1,06(\mathrm{~T})$ & $1,02(\mathrm{~T})$ & $0,97(\mathrm{~T})$ & $0,73(\mathrm{~T})$ & $0,59(\mathrm{~S})$ \\
\hline \multirow{2}{*}{ C-Organik (\%) } & Awal & $1,39(\mathrm{R})$ & $1,86(\mathrm{R})$ & $2,21(\mathrm{~S})$ & $2,29(\mathrm{~S})$ & $2,07(\mathrm{~S})$ & $2,05(\mathrm{~S})$ \\
\hline & Akhir & $1,36(\mathrm{R})$ & $1,79(\mathrm{R})$ & $2,15(\mathrm{~S})$ & $2,61(\mathrm{~S})$ & $2,62(\mathrm{~S})$ & $2,53(\mathrm{~S})$ \\
\hline \multirow{2}{*}{$\mathrm{pH}\left(\mathrm{H}_{2} \mathrm{O}\right)$} & Awal & 6,13 & 6,15 & 6,39 & 6,49 & 6,37 & 6,38 \\
\hline & Akhir & 5,86 & 6,04 & 6,00 & 6,41 & 6,24 & 6,43 \\
\hline
\end{tabular}

Keterangan : A: Kontrol (tanpa pupuk), B: $100 \mathrm{~kg} u r e a ~ h a-1^{-1}, 200 \mathrm{~kg} \mathrm{SP}-36 \mathrm{ha}^{-1}, 100 \mathrm{~kg} \mathrm{KCl} \mathrm{ha}{ }^{-1}$, C: $75 \mathrm{~kg}$ urea $\mathrm{ha}^{-1}, 150 \mathrm{~kg} \mathrm{SP}-36 \mathrm{ha}^{-1}, 75 \mathrm{~kg} \mathrm{KCl} \mathrm{ha}^{-1}, 1.000 \mathrm{~kg}$ Organonitrofos ha- ${ }^{-1}$, D: $50 \mathrm{~kg}$ urea ha- ${ }^{-1}, 100 \mathrm{~kg}$ SP$36 \mathrm{ha}^{-1}, 50 \mathrm{~kg} \mathrm{KCl} \mathrm{ha}{ }^{-1}, 2.500 \mathrm{~kg}$ Organonitrofos ha- ${ }^{-1}$, E: $25 \mathrm{~kg}$ urea ha $^{-1}, 50 \mathrm{~kg} \mathrm{SP}-36 \mathrm{ha}^{-1}, 25 \mathrm{~kg} \mathrm{KCl}$ $\mathrm{ha}^{-1}, 3.000 \mathrm{~kg}$ Organonitrofos ha $\mathrm{ha}^{-1}, \mathrm{~F}: 5.000 \mathrm{~kg}$ Organonitrofos ha- ${ }^{-1}$.Angka yang diikuti huruf menyatakan $\mathrm{T}=$ Tinggi, $\mathrm{S}=$ sedang, $\mathrm{R}=$ rendah (Balai Penelitian Tanah, 2005).

Tabel 3. Pengaruh pupuk Organonitrofos dan kombinasinya dengan pupuk anorganik terhadap serapan unsur hara P-total, P tanaman dan P buah mentimun $\left(\mathrm{kg} \mathrm{ha}^{-1}\right)$.

\begin{tabular}{lccc}
\hline \multirow{2}{*}{$\begin{array}{c}\text { Perlakuan }\left(\mathrm{kg} \mathrm{ha}^{-1}\right) \\
\text { Urea - SP36-KCl - Organonitrofos }\end{array}$} & $\begin{array}{c}\text { Berangkasan } \\
\left(\mathrm{kg} \mathrm{ha}^{-1}\right)\end{array}$ & $\begin{array}{c}\text { Buah } \\
\left(\mathrm{kg} \mathrm{ha}^{-1}\right)\end{array}$ & $\begin{array}{c}\text { P total } \\
\left(\mathrm{kg} \mathrm{ha}^{-1}\right)\end{array}$ \\
\hline A $(0-0-0-0)$ & $1,03 \mathrm{a}$ & $0,86 \mathrm{a}$ & 0,81 \\
B $(100-200-100-0)$ & $1,32 \mathrm{~b}$ & $1,03 \mathrm{~b}$ & 1,81 \\
C $(75-150-75-1.000)$ & $1,30 \mathrm{~b}$ & $1,00 \mathrm{~b}$ & 1,70 \\
D $(50-100-50-2.500)$ & $1,09 \mathrm{a}$ & $1,03 \mathrm{~b}$ & 1,24 \\
E $(25-50-25-3.000)$ & $1,10 \mathrm{ab}$ & $0,96 \mathrm{~b}$ & 1,13 \\
F $(0-0-0-5.000)$ & $1,28 \mathrm{~b}$ & $0,99 \mathrm{~b}$ & 1,63 \\
\hline BNT 0,05 & 0,16 & 0,08 & \\
\hline
\end{tabular}

Keterangan : angka yang diikuti huruf yang sama pada kolom yang sama tidak berbeda nyata pada uji BNT dengan taraf $5 \%$.

mentimun. Hal ini diduga karena pada saat sebelum tanam, lahan diberi pupuk kandang sebanyak $5.000 \mathrm{~kg}$ $\mathrm{ha}^{-1}$ pada setiap plotnya sehingga pada lahan tersebut memiliki ketersediaan unsur hara yang sama. Sama halnya dengan penelitian Sopiyani (2014), menunjukkan bahwa pengaruh pemberian pupuk Organonitrofos dan kombinasinya tidak berpengaruh nyata terhadap pertumbuhan tanaman cabai merah keriting.

Pengaruh Pemupukan Organonitrofos dan Kombinasinya dengan Pupuk Anorganik terhadap
Produksi Tanaman Mentimun. Pemberian pupuk Organonitrofos dan kombinasinya dengan pupuk anorganik tidak berpengaruh nyata terhadap jumlah bunga betina, jumlah bunga jantan, jumlah bunga betina jadi buah dan jumlah buah yang dihasilkan.

Pada jumlah bunga betina (Gambar 3) secara aktual, jumlah bunga hampir merata, yaitu 8 - 9 bunga betina per pohon. Pada jumlah bunga jantan (Gambar 3) secara aktual mampu menghasilkan 12-15 bunga jantan per pohon. Sedangkan pada jumlah bunga betina 
Tabel 4. Pengaruh pupuk Organonitrofos dan kombinasinya dengan pupuk anorganik terhadap serapan unsur hara $\mathrm{K}$-total, $\mathrm{K}$ tanaman dan $\mathrm{K}$ buah mentimun $\left(\mathrm{kg} \mathrm{ha}^{-1}\right)$.

\begin{tabular}{lccc}
\hline \multirow{2}{*}{$\begin{array}{c}\text { Perlakuan }\left(\mathrm{kg} \mathrm{ha}^{-1}\right) \\
\text { Urea }- \text { SP36-KCl - Organonitrofos }\end{array}$} & $\begin{array}{c}\text { Brangkasan } \\
\left(\mathrm{kg} \mathrm{ha}^{-1}\right)\end{array}$ & $\begin{array}{c}\text { Buah } \\
\left(\mathrm{kg} \mathrm{ha}^{-1}\right)\end{array}$ & $\begin{array}{c}\mathrm{K} \text { total } \\
\left(\mathrm{kg} \mathrm{ha}^{-1}\right)\end{array}$ \\
\hline A $(0-0-0-0)$ & $4,04 \mathrm{a}$ & 3,83 & 19,45 \\
B $(100-200-100-0)$ & $5,96 \mathrm{~b}$ & 5,56 & 40,59 \\
C $(75-150-75-1.000)$ & $5,47 \mathrm{~b}$ & 6,17 & 35,68 \\
D $(50-100-50-2.500)$ & $4,84 \mathrm{a}$ & 6,27 & 29,33 \\
E $(25-50-25-3.000)$ & $4,39 \mathrm{a}$ & 6,53 & 25,56 \\
F $(0-0-0-5.000)$ & $5,03 \mathrm{ab}$ & 5,33 & 30,45 \\
\hline BNT 0,05 & 1,01 & & \\
\hline
\end{tabular}

Keterangan : angka yang diikuti huruf yang sama pada kolom yang sama tidak berbeda nyata pada uji BNT dengan taraf $5 \%$.

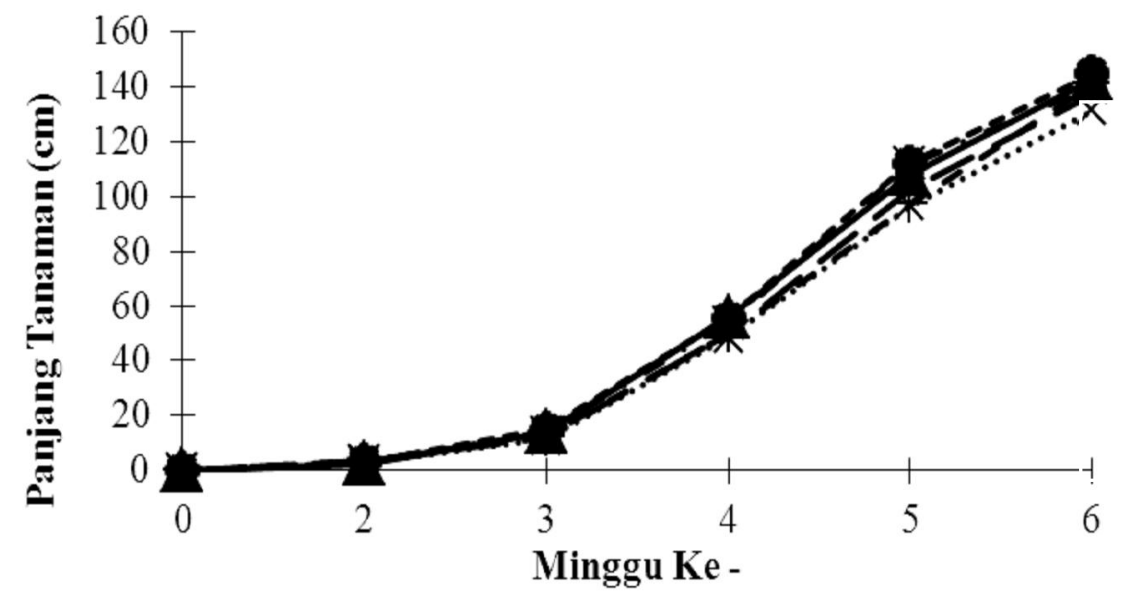

Gambar 1. Pengaruh pupuk Organonitrofos dan kombinasinya dengan pupuk anorganik terhadap panjang tanaman mentimun. Keterangan: $\Varangle \mathrm{A}=$ Kontrol (tanpa pupuk), $-\mathrm{B}=100 \mathrm{~kg}_{\mathrm{rrea}} \mathrm{ha}^{-1}, 200 \mathrm{~kg} \mathrm{SP}-36 \mathrm{ha}^{-1}, 100$ $\mathrm{kg} \mathrm{KCl} \mathrm{ha}{ }^{-1}+{ }^{2}=75 \mathrm{~kg}$ urea ha-1, $150 \mathrm{~kg} \mathrm{SP}-36 \mathrm{ha}^{-1}, 75 \mathrm{~kg} \mathrm{KCl} \mathrm{ha}^{-1}, 1.000 \mathrm{~kg}$ Organonitrofos ha-1, * $\mathrm{D}=50 \mathrm{~kg}$ urea ha-1, $100 \mathrm{~kg} \mathrm{SP}-36 \mathrm{ha}^{-1}, 50 \mathrm{~kg} \mathrm{KCl} \mathrm{ha}{ }^{-1}, 2.500 \mathrm{~kg}^{-}$Organonitrofos ha-1, $\mathrm{E}=25 \mathrm{~kg}$ urea ha-1 $, 50 \mathrm{~kg} \mathrm{SP}^{-36} \mathrm{ha}^{-1}, 25 \mathrm{~kg} \mathrm{KCl} \mathrm{ha}^{-1}, 3.000 \mathrm{~kg}$ Organonitrofos ha ${ }^{-1},-\mathbf{A}=5.000 \mathrm{~kg}$ Organonitrofos ha $^{-1}$.

jadi buah (Gambar 3) secara aktual rata-rata hanya 4 bunga yang menjadi buah per pohonnya.

Hal ini diduga karena kurangnya ketersediaan air bagi tanaman sehingga tanaman tidak dapat berkembang secara optimal. Menurut Zulyana (2011), ketersediaan unsur hara, air dan cahaya matahari yang baik pada tanaman akan memperlancar fotosintesis. Fotosintesis akan menghasilkan fotosintat yang akan digunakan untuk pertumbuhan dan untuk pembentukan bunga, biji dan buah.

Rendahnya jumlah bunga betina diduga karena masih terdapat naungan di sekitar lahan sehingga menghalangi tanaman untuk mendapatkan sinar matahari untuk proses fotosintesis. Pada jumlah bunga jantan, kemunculan bunga terbanyak dapat ditemukan pada perlakuan F (5.000 kg Organonitrofos $\mathrm{ha}^{-1}$ ) dengan jumlah 15 bunga per pohonnya. Pada perlakuan F (5.000 $\mathrm{kg}$ Organonitrofos ha ${ }^{-1}$ ) paling banyak menghasilkan jumlah bunga betina jadi buah maupun jumlah buah per pohon. Untuk jumlah bunga betina menjadi buah menghasilkan 5,33 bunga betina yang menjadi buah, sedangkan jumlah buah yang dihasilkan adalah 4,72 buah per pohon. Hal tersebut menunjukkan bahwa perlakuan menggunakan pupuk tunggal Organonitrofos dapat merangsang pembungaan dan menghasilkan bunga jantan paling banyak. 


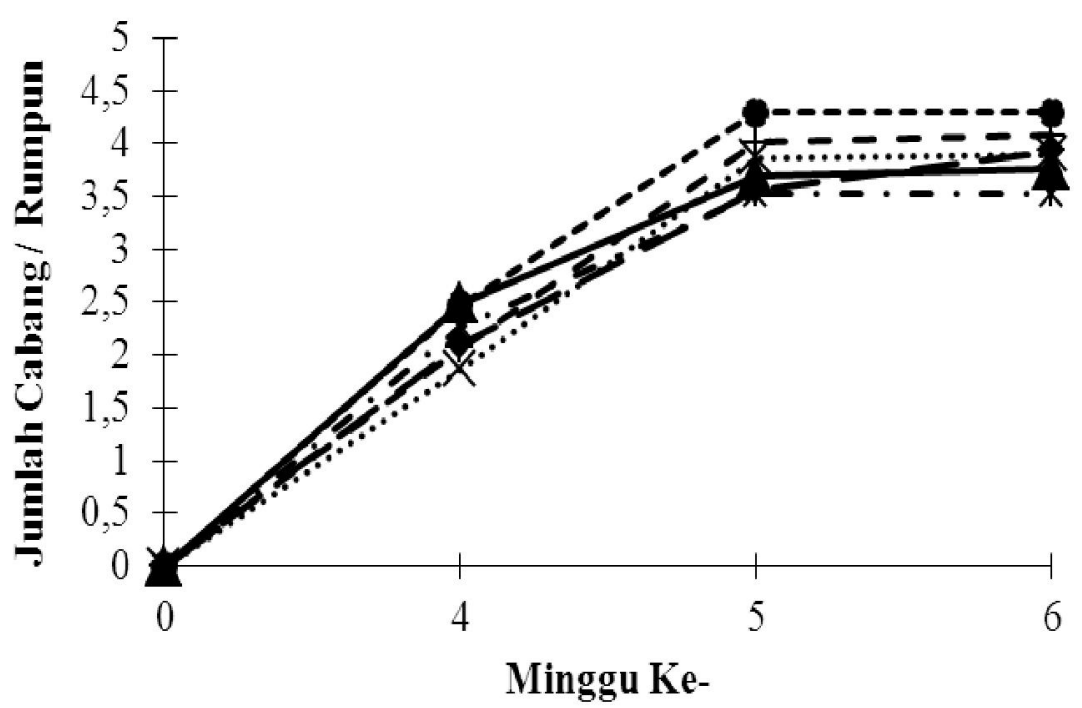

Gambar 1. Pengaruh pupuk Organonitrofos dan kombinasinya dengan pupuk anorganik terhadap jumlah cabang tanaman mentimun. Keterangan: $\Varangle \mathrm{A}=$ Kontrol (tanpa pupuk), $-\mathrm{O}-\mathrm{B}=100 \mathrm{~kg}$ urea ha ${ }^{-1}, 200 \mathrm{~kg}$ SP-36 $\mathrm{ha}^{-1}, 100 \mathrm{~kg}+\beth 1 \mathrm{ha}^{-1}, \mathrm{C}=75 \mathrm{~kg}$ urea ha- ${ }^{-1}, 150 \mathrm{~kg} \mathrm{SP}^{-36} \mathrm{ha}^{-1}, 75 \mathrm{~kg} \mathrm{KCl} \mathrm{ha}^{-1}, 1.000 \mathrm{~kg}$ Organonitrofos ha $^{-1}$, * D $=50 \mathrm{~kg} u r e a ~ h a^{-1}, 100 \mathrm{~kg} \mathrm{SP}-36 \mathrm{ha}^{-1}, 50 \mathrm{~kg} \mathrm{KCl} \mathrm{ha}^{-1}, 2.500 \mathrm{~kg}$ Organonitrofos ha $\mathrm{k}^{-1}-\mathrm{E}$

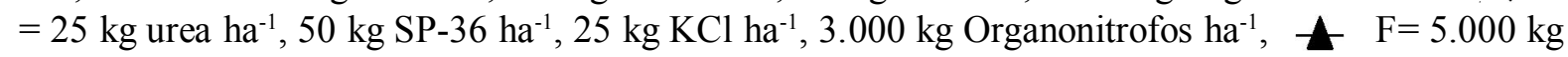
Organonitrofos $\mathrm{ha}^{-1}$.

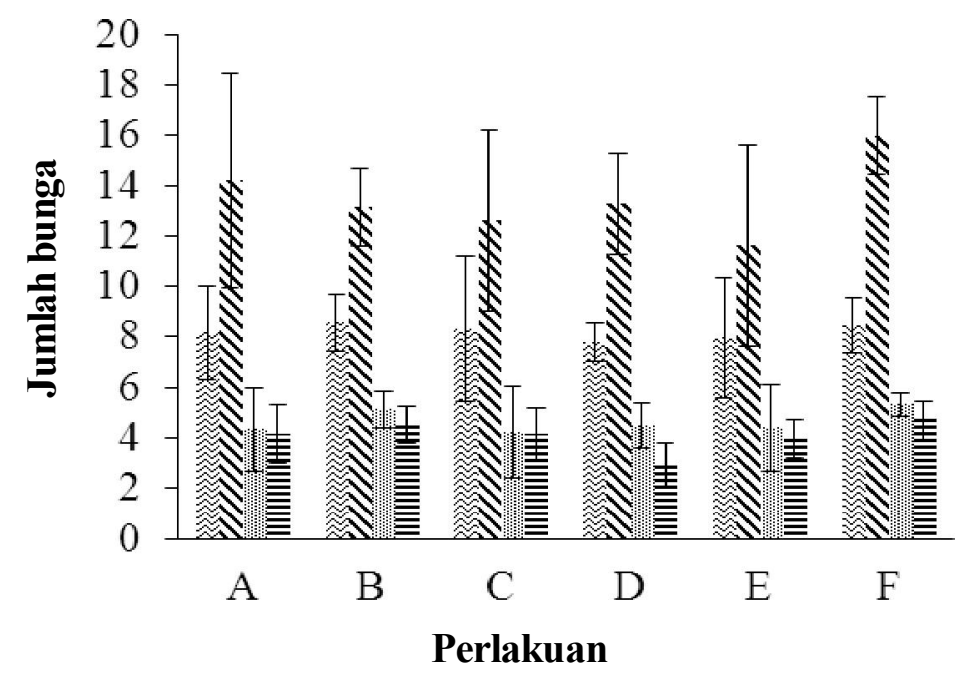

Gambar 3. Pengaruh pupuk Organonitrofos dan kombinasinya dengan pupuk anorganik terhadap jumlah bunga betina, jumlah bunga jantan, jumlah bunga jadi buah dan jumlah buah yang dihasilkan tanaman mentimu. Keterangan: $\mathrm{A}=$ Kontrol(tanpa pupuk), $\mathrm{B}=100 \mathrm{~kg}$ urea ha $^{-1}, 200 \mathrm{~kg} \mathrm{SP}-36 \mathrm{ha}^{-1}, 100 \mathrm{~kg} \mathrm{KCl} \mathrm{ha}^{-1}$,

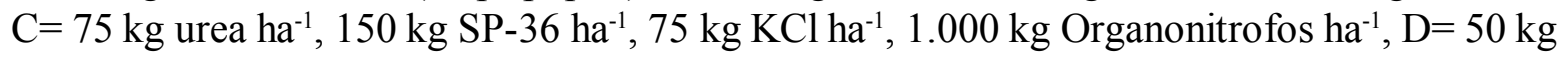
urea ha ${ }^{-1}, 100 \mathrm{~kg} \mathrm{SP}-36 \mathrm{ha}^{-1}, 50 \mathrm{~kg} \mathrm{KCl} \mathrm{ha}{ }^{-1}, 2.500 \mathrm{~kg}^{-}$Organonitrofos ha- ${ }^{-1}, \mathrm{E}=25 \mathrm{~kg}^{-1}$ urea ha $^{-1}, 50$ $\mathrm{kg} \mathrm{SP}-36 \mathrm{ha}^{-1}, 25 \mathrm{~kg} \mathrm{KCl} \mathrm{ha}^{-1}, 3.000 \mathrm{~kg}$ Organonitrofos ha- $^{-1}, \mathrm{~F}=5.000 \mathrm{~kg}$ Organonitrofos ha- ${ }^{-1}$. $\mathcal{\&}$ =bunga betina; $\mathbf{X}$ = bunga jantan; $\because$ = bunga betina jadi buah; $\mathbf{\Xi}=$ jumlah buah panen.

Meskipun jumlah buah berkaitan erat dengan jumlah bunga betina per pohon, namun keterkaitan jumlah buah dengan jumlah betina tidaklah mutlak, karena selama masa perkembangan bunga menjadi buah banyak sekali faktor yang menghalangi terbentuknya bunga menjadi buah. Faktor tersebut diantaranya suhu yang tinggi dapat menggagalkan pembentukan buah. Ratarata persen kerontokan bunga betina jadi buah yaitu 12,45\%. Menurut Zulyana (2011), jumlah bunga betina yang sedikit akan memberikan hasil buah yang sedikit pula, namun jumlah bunga betina yang banyak belum tentu memberikan hasil buah yang banyak, semua 


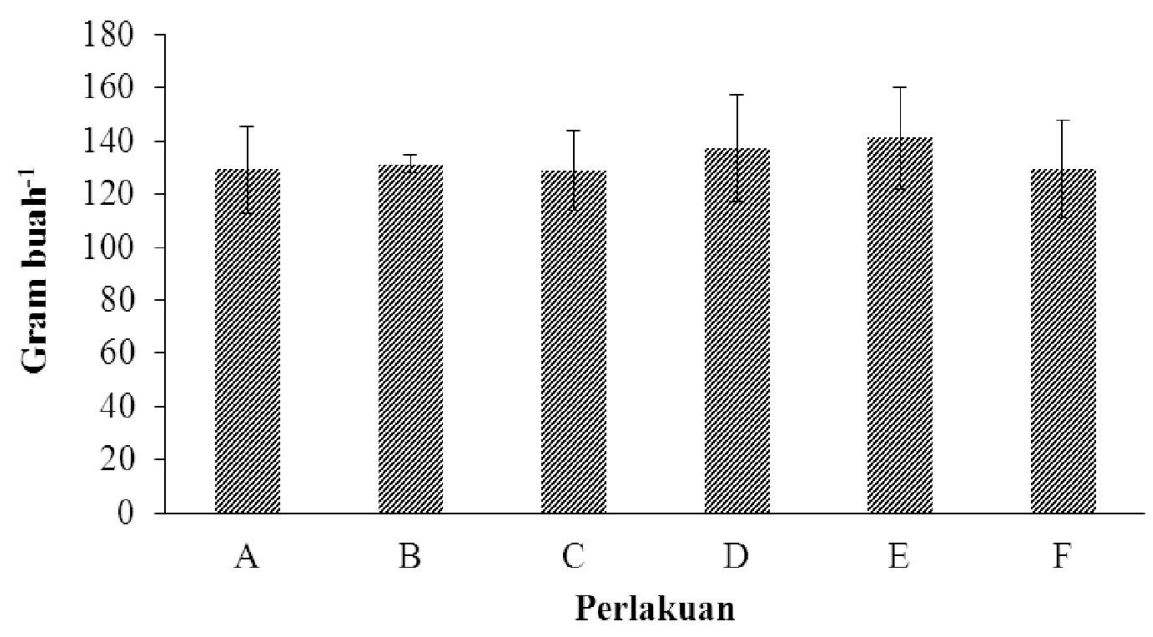

Gambar 4. Pengaruh pupuk Organonitrofos dan kombinasinya dengan pupuk anorganik terhadap bobot rata-rata buah mentimun. Keterangan: A: Kontrol (tanpa pupuk), B: $100 \mathrm{~kg}_{\text {urea ha }}{ }^{-1}, 200 \mathrm{~kg} \mathrm{SP}-36 \mathrm{ha}^{-1}, 100$ $\mathrm{kg} \mathrm{KCl} \mathrm{ha}{ }^{-1}, \mathrm{C}: 75 \mathrm{~kg}$ urea ha-1 $, 150 \mathrm{~kg} \mathrm{SP}-36 \mathrm{ha}^{-1}, 75 \mathrm{~kg} \mathrm{KCl} \mathrm{ha}^{-1}, 1.000 \mathrm{~kg}^{-1}$ Organonitrofos ha- ${ }^{-1}$, D: $50 \mathrm{~kg}$ urea ha- ${ }^{-1}, 100 \mathrm{~kg} \mathrm{SP}-36 \mathrm{ha}^{-1}, 50 \mathrm{~kg} \mathrm{KCl} \mathrm{ha}{ }^{-1}, 2.500 \mathrm{~kg}$ Organonitrofos ha ${ }^{-1}$, E: $25 \mathrm{~kg}$ urea ha- ${ }^{-1}$, $50 \mathrm{~kg} \mathrm{SP}-36 \mathrm{ha}^{-1}, 25 \mathrm{~kg} \mathrm{KCl} \mathrm{ha}^{-1}, 3.000 \mathrm{~kg}$ Organonitrofos ha-1, F: $5.000 \mathrm{~kg}$ Organonitrofos ha-1.

tergantung pada proses atau hambatan yang terjadi selama penyerbukan dan lingkungan selama pembentukan dan pemasakan buah.

Gagalnya pembentukan bunga dari suatu tanaman disebabkan oleh ekologi (suhu, angin, kelembaban dan sebagainya), zat makanan yang tidak seimbang (terutama $\mathrm{N}, \mathrm{P}$ dan $\mathrm{K}$ ), air yang berlebihan atau kekurangan air, penyerbukan dan pembuahan, serangga penyerbukan sedikit atau tidak ada, gangguan hama dan penyakit, genotif susunan kromosom buah (Sunarjono, 2004).

Data hasil penelitian menunjukkan bahwa pengaruh pupuk Organonitrofos dan kombinasinya dengan pupuk anorganik tidak berpengaruh terhadap bobot rata-rata buah mentimun (Gambar 4). Bobot buah mentimun sangat dipengaruhi oleh laju fotositesis. Apabila ketersediaan air, unsur hara dan cahaya matahari berkurang, maka akan mempengaruhi laju fotosintesis yang kemudian akan mengakibatkan penurunan produksi suatu tanaman (Gardner dkk, 1991).

Pupuk Organonitrofos dan kombinasinya dengan pupuk anorganik tidak berpengaruh terhadap produksi buah segar dan bobot kering buah mentimun (Gambar 5). Namun, ada kecenderungan bahwa pemberian pupuk tunggal Organonitrofos, perlakuan F $(5.000 \mathrm{~kg}$ Organonitrofos $\mathrm{ha}^{-1}$ ) mampu memberikan produksi lebih tinggi dibandingkan perlakuan A (Kontrol) yaitu menghasilkan 29,03 $\mathrm{t} \mathrm{ha}^{-1}$ sedangkan perlakuan A (Kontrol) hanya mampu menghasilkan 21,20 $\mathrm{t} \mathrm{ha}^{-1}$.

Tidak responsif tanaman terhadap perlakuan yang diterapkan diduga karena kondisi cuaca yang kering, sehingga pengairan yang dilakukan tidak mampu memenuhi kebutuhan air bagi tanaman. Perlu diketahui bahwa air merupakan faktor pembatas utama dalam budidaya mentimun. Selain itu, adanya serangan hama dan penyakit juga sangat berpengaruh terhadap tanaman mentimun sehingga pembentukan buah terhambat dan tidak mencapai produksi secara maksimal.

Hama yang menyerang pada fase pembuahan mentimun adalah ulat grayak, serangga Leptoglossus australis dan lalat penggorok daun. Pengaruh hama ini sangat besar dampaknya karena akan mempengaruhi daun dan bentuk buah.

Pada penelitian ini yang menyebabkan pertumbuhan dan produksi terganggu bukan hanya hama, tetapi juga penyakit. Pada lahan penelitian ini penyakit bercak daun juga ditemukan pada tanaman mentimun. Gejala yang ditunjukkan adalah bercak berbentuk bulat dan bercak coklat yang dikelilingi halo berwarna kuning. Di Amerika, penyakit bercak daun yang disebabkan oleh patogen Colletotrichum ini dapat menurunkan produksi hingga 63\% (Amin dan Ullasa, 1981).

Berdasarkan anara, pemberian pupuk Organonitrofos dan kombinasinya dengan pupuk anorganik tidak berpengaruh nyata terhadap bobot basah dan bobot kering tanaman mentimun (Gambar 6). Tanaman mentimun merupakan tanaman yang memiliki kadar air tinggi baik buah maupun tanaman. Untuk kadar air tanaman sekitar $79-84 \%$, hal ini berpengaruh terhadap peningkatan bobot basah. Dwijoseputro (1980), menyatakan bobot basah dipengaruhi oleh kadar air dan kandungan unsur hara yang ada dalam sel-sel jaringan, semakin tinggi serapan air dan unsur hara maka bobot basah brangkasan akan semakin meningkat. 
Pada perlakuan C (75 kg urea ha ${ }^{-1}, 150 \mathrm{~kg} \mathrm{SP-36}$ $\mathrm{ha}^{-1}, 75 \mathrm{~kg} \mathrm{KCl} \mathrm{ha}{ }^{-1}, 1.000 \mathrm{~kg}$ Organonitrofos ha ${ }^{-1}$ ) kombinasi antara pupuk Organonitrofos dan pupuk anorganik memberikan nilai bobot kering tertinggi yaitu 1,73 ton ha-1. Yupitasari (2013), menyatakan aplikasi $100 \mathrm{~kg}$ urea ha- ${ }^{-1}, 50 \mathrm{~kg}$ SP-36 ha ${ }^{-1}, 50 \mathrm{~kg} \mathrm{KCl} \mathrm{ha}{ }^{-1}$, $1.000 \mathrm{~kg}$ Organonitrofos ha ${ }^{-1}$ memberikan hasil bobot kering berangkasan tanaman tomat tertinggi, dibandingkan dengan perlakuan kontrol (Gambar 7).
Peningkatan bobot kering tanaman diduga karena dipengaruhi oleh serapan hara $\mathrm{N}, \mathrm{P}$ dan $\mathrm{K}$, dimana serapan hara tersebut mempengaruhi proses fotosintesis sehingga tanaman mentimun memiliki batang, daun dan cabang yang kokoh. Sebagai pupuk organik, penggunaan pupuk Organonitrofos memberikan pengaruh yang baik bagi sistem pertanian jika dilakukan secara kontinyu.

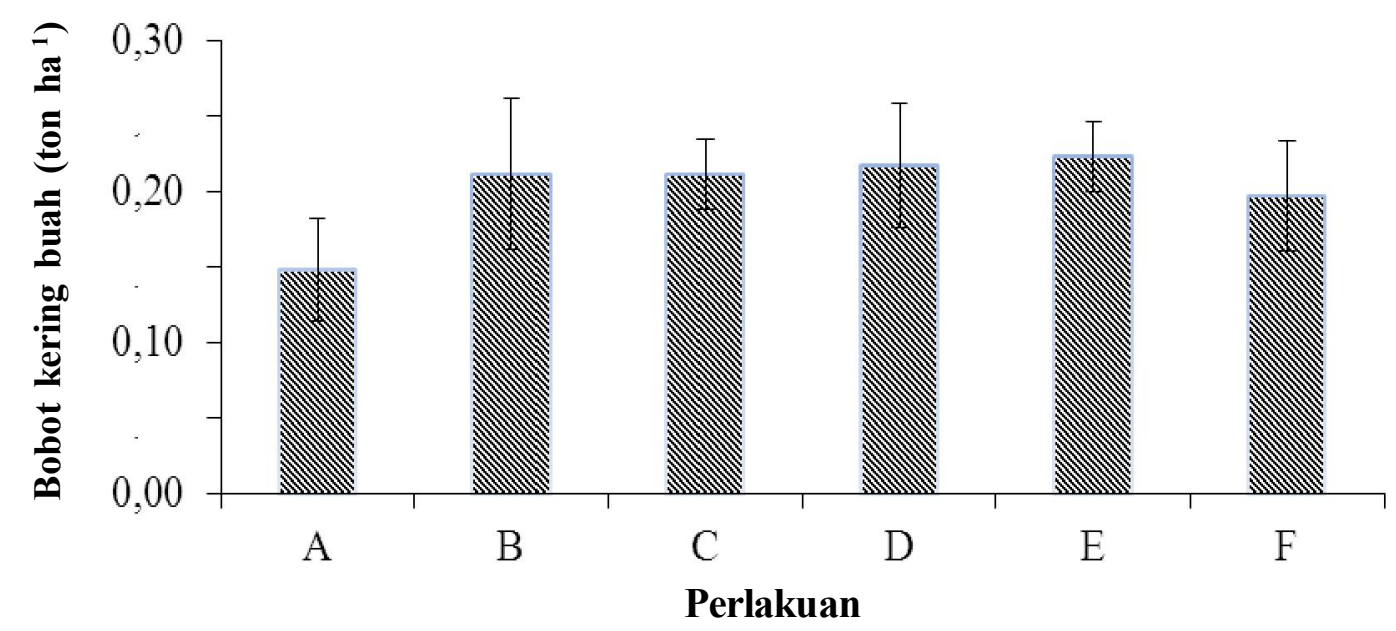

Gambar 6. Pengaruh pupuk Organonitrofos dan kombinasinya dengan pupuk anorganik terhadap bobot buah kering tanaman mentimun. Keterangan: $\mathrm{A}=$ Kontrol (tanpa pupuk), B= $100 \mathrm{~kg}$ urea ha ${ }^{-1}, 200 \mathrm{~kg}$ SP-36 $\mathrm{ha}^{-1}, 100 \mathrm{~kg} \mathrm{KCl} \mathrm{ha}{ }^{-1}, \mathrm{C}=75 \mathrm{~kg} \mathrm{urea} \mathrm{ha}^{-1}, 150 \mathrm{~kg} \mathrm{SP}-36 \mathrm{ha}^{-1}, 75 \mathrm{~kg} \mathrm{KCl} \mathrm{ha}^{-1}, 1.000 \mathrm{~kg}$ Organonitrofos $\mathrm{ha}^{-1}, \mathrm{D}=50 \mathrm{~kg} \mathrm{urea} \mathrm{ha}^{-1}, 100 \mathrm{~kg} \mathrm{SP}-36 \mathrm{ha}^{-1}, 50 \mathrm{~kg} \mathrm{KCl} \mathrm{ha}{ }^{-1}, 2.500 \mathrm{~kg}$ Organonitrofos ha ${ }^{-1}, \mathrm{E}=25 \mathrm{~kg}$ urea ha-1, $50 \mathrm{~kg} \mathrm{SP}-36 \mathrm{ha}^{-1}, 25 \mathrm{~kg} \mathrm{KCl} \mathrm{ha}^{-1}, 3.000 \mathrm{~kg}^{-}$Organonitrofos ha ${ }^{-1}, \mathrm{~F}=5.000 \mathrm{~kg}$ Organonitrofos $\mathrm{ha}^{-1}$.

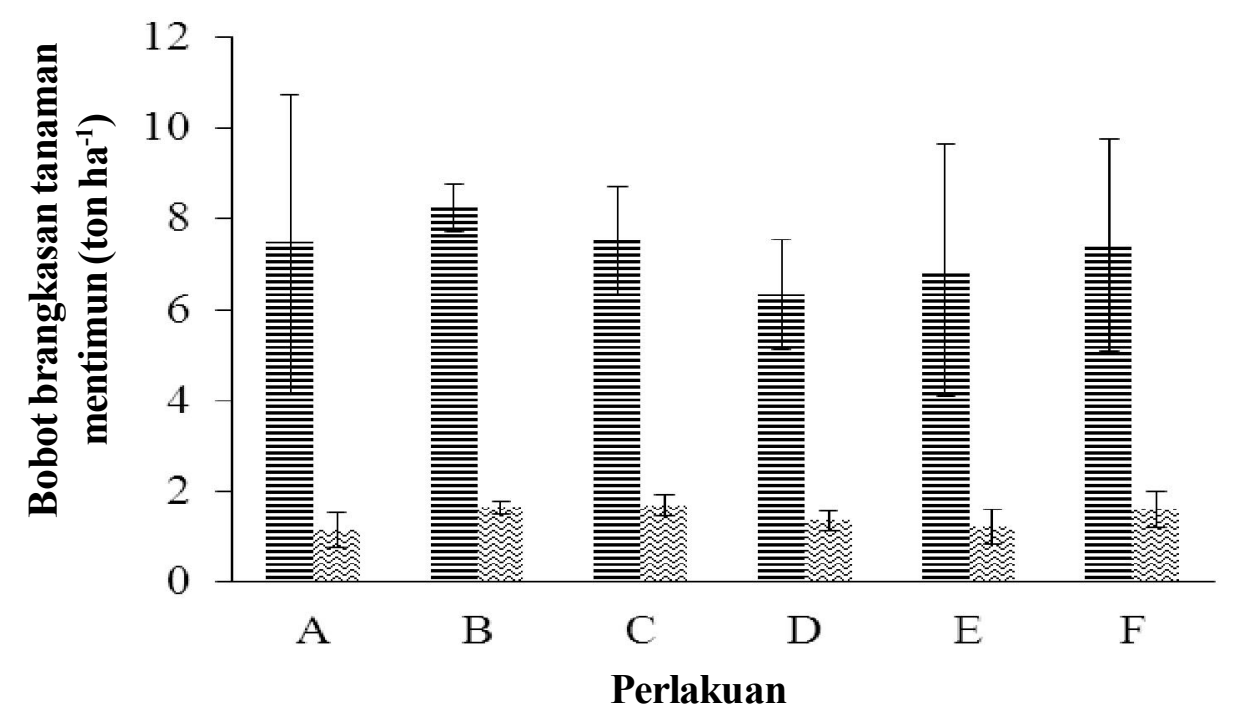

Gambar 7. Pengaruh pupuk Organonitrofos dan kombinasinya dengan pupuk anorganik terhadap bobot brangkasan tanaman mentimun. Keterangan: $\mathrm{A}=$ Kontrol (tanpa pupuk), $\mathrm{B}=100 \mathrm{~kg}^{\mathrm{urea} \mathrm{ha}} \mathrm{h}^{-1}, 200 \mathrm{~kg} \mathrm{SP}-36 \mathrm{ha}^{-1}$, $100 \mathrm{~kg} \mathrm{KCl} \mathrm{ha}^{-1}, \mathrm{C}=75 \mathrm{~kg}$ urea ha ${ }^{-1}, 150 \mathrm{~kg} \mathrm{SP}-36 \mathrm{ha}^{-1}, 75 \mathrm{~kg} \mathrm{KCl} \mathrm{ha}^{-1}, 1.000 \mathrm{~kg}$ Organonitrofos ha- ${ }^{-1}$, $\mathrm{D}=50 \mathrm{~kg}$ urea ha- ${ }^{-1}, 100 \mathrm{~kg} \mathrm{SP}-36 \mathrm{ha}^{-1}, 50 \mathrm{~kg} \mathrm{KCl} \mathrm{ha}^{-1}, 2.500 \mathrm{~kg}^{-}$Organonitrofos ha ${ }^{-1}, \mathrm{E}=25 \mathrm{~kg}$ urea ha-

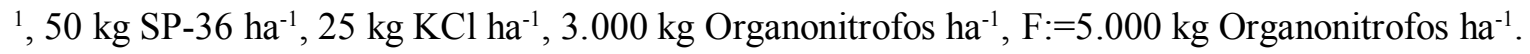


Berdasarkan analisis ragam pemberian pupuk Organonitrofos dan kombinasinya dengan pupuk anorganik tidak berpengaruh nyata terhadap serapan $\mathrm{N}$ tanaman dan buah mentimun (Gambar 8). Hal ini diduga karena kandungan $\mathrm{N}$ pada tanah banyak yang menguap karena cuaca sangat kering dan panas.

Selain itu, berdasarkan hasil uji BNT pengaruh pupuk Organonitrofos dan kombinasinya dengan pupuk anorganik berbeda nyata terhadap serapan $\mathrm{P}$ tanaman dan berbeda nyata terhadap P buah (Tabel 3).

Hasil uji BNT, perlakuan C (75 kg urea ha ${ }^{-1}, 150$ kg SP-36 ha-1, $75 \mathrm{~kg} \mathrm{KCl} \mathrm{ha-1,} 1.000 \mathrm{~kg}$ Organonitrofos $\mathrm{ha}^{-1}$ ) berbeda nyata dengan perlakuan A (kontrol). Serapan hara P-Total tertinggi dimiliki oleh perlakuan B (100 kg urea ha ${ }^{-1}, 200 \mathrm{~kg} \mathrm{SP}-36 \mathrm{ha}^{-1}, 100 \mathrm{~kg} \mathrm{KCl} \mathrm{ha}{ }^{-1}$ ) dengan berat $1,81 \mathrm{~kg} \mathrm{ha}^{-1}$. Selain itu pemberian pupuk Organonitrofos dan kombinasinya dengan pupuk anorganik, perlakuan C (75 kg urea ha ${ }^{-1}, 150 \mathrm{~kg} \mathrm{SP}-36$ $\mathrm{ha}^{-1}, 75 \mathrm{~kg} \mathrm{KCl} \mathrm{ha} \mathrm{ha}^{-1}, 1.000 \mathrm{~kg}$ Organonitrofos ha ${ }^{-1}$ ) memiliki serapan $\mathrm{P}$ total tertinggi ke-dua dengan berat $1,70 \mathrm{~kg} \mathrm{ha}^{-1}$. Terlihat pada (Tabel 2) P-tersedia dalam tanah sangat rendah, hal ini diduga karena serapan $\mathrm{P}$ banyak diserap oleh tanaman dan buah mentimun.

Pupuk Organonitrofos dan kombinasinya dengan pupuk anorganik berbeda nyata terhadap serapan hara $\mathrm{K}$ tanaman mentimun, tetapi tidak berpengaruh terhadap serapan hara K oleh buah mentimun. Serapan hara tanaman tertinggi terdapat pada perlakuan B $(100 \mathrm{~kg}$ urea ha-1, $200 \mathrm{~kg} \mathrm{SP}^{-36 \mathrm{ha}^{-1}, 100 \mathrm{~kg} \mathrm{KCl} \mathrm{ha}}{ }^{-1}$ ) sebanyak $35,02 \mathrm{~kg} \mathrm{ha}^{-1}$. Sedangkan serapan $\mathrm{K}$ oleh buah tertinggi terdapat pada perlakuan E ( $25 \mathrm{~kg}$ urea ha ${ }^{-1}, 50 \mathrm{~kg} \mathrm{SP}-$ $36 \mathrm{ha}^{-1}, 25 \mathrm{~kg} \mathrm{KCl} \mathrm{ha}^{-1}, 3.000 \mathrm{~kg}$ Organonitrofos ha- ${ }^{-1}$ ). Namun, bila melihat serapan K-total tertinggi ke-dua terdapat pada perlakuan C (75 kg urea ha- ${ }^{-1}, 150 \mathrm{~kg}$ SP$36 \mathrm{ha}^{-1}, 75 \mathrm{~kg} \mathrm{KCl} \mathrm{ha}{ }^{-1}, 1.000 \mathrm{~kg}$ Organonitrofos ha- $\left.{ }^{-1}\right)$ yaitu $35,68 \mathrm{~kg} \mathrm{ha}^{-1}$, hal ini menunjukkan kombinasi pupuk Organonitrofos dengan pupuk anorganik mampu meningkatkan serapan hara tanaman dan buah mentimun. Unsur K biasanya dibutuhkan dalam jumlah banyak bagi tanaman dan buah. Menurut Tresya (2012), manfaat unsur hara $\mathrm{K}$ ini biasanya untuk memperlancar proses fotosintesa, memacu pertumbuhan tanaman pada tingkat permulaan, memperkuat ketegaran batang sehingga mengurangi resiko mudah rebah, mengurangi kecepatan pembusukan hasil selama pengangkutan dan penyimpanan, menambah daya tahan tanaman terhadap serangan hama, penyakit dan kekeringan, memperbaiki mutu hasil yang berupa bunga dan buah (rasa dan warna).

Dari uraian di atas dapat disimpulkan bahwa baik pemberian pupuk tunggal anorganik maupun pemberian pupuk Organonitrofos dan kombinasinya dengan pupuk anorganik mampu meningkatkan serapan hara N, P dan $\mathrm{K}$ pada tanaman dan buah mentimun. Dosis terbaik dalam meningkatkan serapan hara $\mathrm{N}, \mathrm{P}$ dan $\mathrm{K}$ terdapat pada perlakuan C (75 kg urea ha-1, $150 \mathrm{~kg} \mathrm{SP}-36 \mathrm{ha}^{-1}$, $75 \mathrm{~kg} \mathrm{KCl} \mathrm{ha} \mathrm{ha}^{-1}, 1.000 \mathrm{~kg}$ Organonitrofos ha $\mathrm{h}^{-1}$ ) dan B (100 kg urea ha ${ }^{-1}, 200 \mathrm{~kg} \mathrm{SP-36} \mathrm{ha-1,100} \mathrm{kg} \mathrm{KCl} \mathrm{ha-1).}$ Namun bila ditinjau dari segi ramah lingkungan, sebaiknya menggunakan pupuk tunggal Organonitrofos

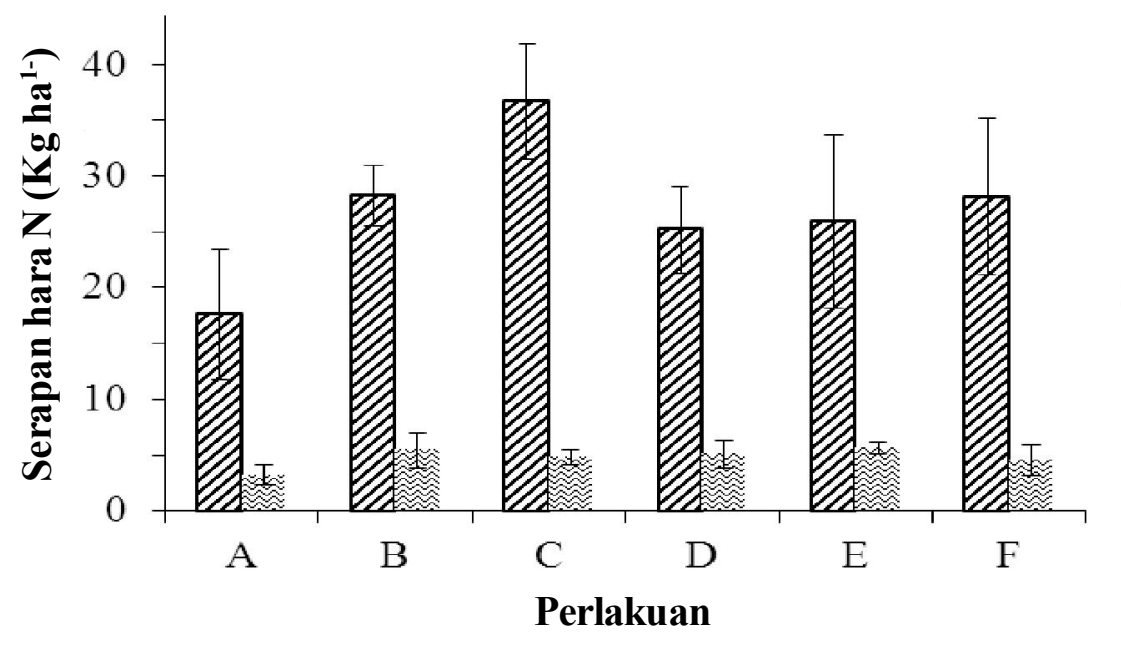

Gambar 8. Pengaruh pupuk Organonitrofos dan kombinasinya dengan pupuk anorganik terhadap serapan unsur hara $\mathrm{N}$ tanaman dan $\mathrm{N}$ buah mentimun $\left(\mathrm{kg} \mathrm{ha}^{-1}\right)$. Keterangan: $\mathrm{A}=$ Kontrol (tanpa pupuk), $\mathrm{B}=100 \mathrm{~kg}$ urea ha-1, $200 \mathrm{~kg} \mathrm{SP}^{-36} \mathrm{ha}^{-1}, 100 \mathrm{~kg} \mathrm{KCl} \mathrm{ha}{ }^{-1}, \mathrm{C}=75 \mathrm{~kg} \mathrm{urea} \mathrm{ha}^{-1}, 150 \mathrm{~kg} \mathrm{SP}-36 \mathrm{ha}^{-1}, 75 \mathrm{~kg} \mathrm{KCl} \mathrm{ha}{ }^{-1}$, $1.000 \mathrm{~kg}$ Organonitrofos ha- ${ }^{-1}, \mathrm{D}=50 \mathrm{~kg}$ urea ha-1, $100 \mathrm{~kg} \mathrm{SP}^{-36} \mathrm{ha}^{-1}, 50 \mathrm{~kg} \mathrm{KCl} \mathrm{ha}{ }^{-1}, 2.500 \mathrm{~kg}$ Organonitrofos ha $\mathrm{h}^{-1}, \mathrm{E}=25 \mathrm{~kg}$ urea ha- ${ }^{-1}, 50 \mathrm{~kg} \mathrm{SP}-36 \mathrm{ha}^{-1}, 25 \mathrm{~kg} \mathrm{KCl} \mathrm{ha}{ }^{-1}, 3.000 \mathrm{~kg}$ Organonitrofos $\mathrm{ha}^{-1}, \mathrm{~F}=5.000 \mathrm{~kg}$ Organonitrofos ha-1 $. \mathbb{Z}=$ tanaman; $\approx=$ bunga. 
atau pupuk Organonitrofos dan kombinasinya dengan pupuk anorganik untuk mengurangi penggunaan pupuk anorganik yang berlebihan dan dapat merusak lingkungan. Selain itu, pemberian pupuk tunggal Organonitrofos atau pupuk Organonitrofos dan kombinasinya dengan pupuk anorganik sudah mampu memberikan nutrisi dan unsur hara yang cukup bagi pertumbuhan tanaman mentimun, sehingga dapat meningkatkan produksi dan serapan hara $\mathrm{N}, \mathrm{P}$ dan $\mathrm{K}$ tanaman mentimun.

Berdasarkan hasil uji korelasi antar variabel seperti yang disajikan pada (Tabel 5) terdapat korelasi nyata antara serapan hara $\mathrm{N}$ dan $\mathrm{K}$ terhadap pertumbuhan tanaman dan korelasi nyata antara serapan hara $\mathrm{N}, \mathrm{P}$ dan $\mathrm{K}$ terhadap bobot berangkasan.

Semakin tinggi serapan hara N, P dan K maka akan semakin tinggi pula bobot berangkasan tanaman mentimun. Hal ini diduga karena adanya hubungan erat antara kadar $\mathrm{N}, \mathrm{P}$ dan $\mathrm{K}$ dengan bobot berangkasan tanaman mentimun.

Namun pada serapan $\mathrm{P}$ terhadap panjang tanaman dan jumlah cabang berkorelasi negatif. Hal ini diduga karena unsur hara $\mathrm{P}$ sukar larut dalam tanah dan menyebabkan proses dekomposisinya berjalan lambat sehingga unsur hara $\mathrm{P}$ hanya sedikit yang bisa diserap oleh tanaman. Selain itu, serapan hara N, P dan K juga memberikan korelasi tidak nyata terhadap bobot buah segar mentimun. Hal ini diduga karena unsur hara N, P dan $\mathrm{K}$ banyak digunakan pada fase pertumbuhan vegetatif sehingga pada masa fase generatif unsur hara $\mathrm{N}, \mathrm{P}$ dan $\mathrm{K}$ hanya tersedia sedikit dan belum mencukupi kebutuhan hara dalam pembentukan buah. Pada umumnya tanaman sangat membutuhkan unsur hara dalam jumlah banyak, sehingga kebutuhan hara bagi tanaman akan terpenuhi untuk pertumbuhan dan perkembangan tanaman. Oleh karena itu ketersediaan unsur hara yang cukup dan seimbang sangat diperlukan bagi tanaman karena sangat mempengaruhi dalam proses perombakan unsur hara, fotosisntesis, dan perkembangan tanaman itu sendiri.

Berdasarkan perhitungan RAE (Relative Agronomic Effectiveness), pupuk tunggal Organonitrofos maupun kombinasi pupuk Organonitrofos dengan pupuk anorganik secara agronomis sangat baik digunakan untuk tanaman mentimun dimana memiliki nilai RAE lebih besar dari $100 \%$ (Tabel 6). RAE pada perlakuan C (75 kg urea $\mathrm{ha}^{-1}, 150 \mathrm{~kg} \mathrm{SP}-36 \mathrm{ha}^{-1}, 75 \mathrm{~kg} \mathrm{KCl} \mathrm{ha}{ }^{-1}, 1.000 \mathrm{~kg}$ Organonitrofos $\mathrm{ha}^{-1}$ ) bersifat efektif terhadap total biomass karena memiliki nilai RAE lebih besar dari $100 \%$. Sedangkan RAE pada perlakuan F $(5.000 \mathrm{~kg}$ Organonitrofos $\mathrm{ha}^{-1}$ ) bersifat efektif terhadap total bobot buah segar karena memiliki nilai RAE lebih besar dari $100 \%$. Hal ini menunjukkan bahwa pupuk tunggal Organonitrofos maupun kombinasi pupuk Organonitrofos dengan pupuk anorganik dapat digunakan sebagai alternatif pengganti pupuk anorganik dan mengefisienkan penggunaan pupuk anorganik dalam budidaya mentimun.

Uji ekonomis pupuk dimaksudkan untuk mengetahui apakah pupuk yang diuji layak digunakan dan menguntungkan sebagai usahatani mentimun. Uji ekonomi dilakukan dengan menghitung rasio penerimaan pendapatan maupun pengeluaran biaya pupuk. Berdasarkan hasil uji ekonomis, dapat diketahui bahwa pupuk tunggal Organonitrofos, kombinasi pupuk

Tabel 5. Uji korelasi serapan hara N, P dan K terhadap pertumbuhan dan produksi tanaman mentimun.

\begin{tabular}{cllc}
\hline No & \multicolumn{1}{c}{ Uji Korelasi } & \multicolumn{1}{c}{ Persamaan } & $\mathrm{R}$ \\
\hline 1 & Serapan hara N vs Panjang tanaman & $\mathrm{y}=1,06 \mathrm{x}+111,19$ & $0,48^{*}$ \\
2 & Serapan hara P vs Panjang tanaman & $\mathrm{y}=22,74 \mathrm{x}+118,65$ & $0,45 \mathrm{tn}$ \\
3 & Serapan hara K vs Panjang tanaman & $\mathrm{y}=1,07 \mathrm{x}+113,36$ & $0,50 *$ \\
4 & Serapan hara N vs Jumlah cabang & $\mathrm{y}=0,05 \mathrm{x}+2,41$ & $0,47 *$ \\
5 & Serapan hara P vs Jumlah cabang & $\mathrm{y}=0,90 \mathrm{x}+2,95$ & $0,36 \mathrm{tn}$ \\
6 & Serapan hara K vs Jumlah cabang & $\mathrm{y}=0,04 \mathrm{x}+2,90$ & $0,34 \mathrm{tn}$ \\
7 & Serapan hara N vs Bobot segar buah & $\mathrm{y}=-0,18 \mathrm{x}+23,47$ & $0,03 \mathrm{tn}$ \\
8 & Serapan hara P vs Bobot segar buah & $\mathrm{y}=-0.68 \mathrm{x}+22.94$ & $0,01 \mathrm{tn}$ \\
9 & Serapan hara K vs Bobot segar buah & $\mathrm{y}=-0,65 \mathrm{x}+26,29$ & $0,13 \mathrm{tn}$ \\
10 & Serapan hara N vs Bobot brangkasan & $\mathrm{y}=0,12 \mathrm{x}+3,95$ & $0,50 *$ \\
11 & Serapan hara P vs Bobot brangkasan & $\mathrm{y}=2,94 \mathrm{x}+4,58$ & $0,51 *$ \\
12 & Serapan hara K vs Bobot brangkasan & $\mathrm{y}=0,13 \mathrm{x}+4,07$ & $0,53 *$ \\
\hline
\end{tabular}

Keterangan : $\mathrm{tn}=$ tidak berbeda nyata pada taraf $5 \%, *=$ berbeda nyata pada taraf $5 \%$. 
Organonitrofos dengan pupuk anorganik dan pupuk rekomendasi memiliki nilai ekonomis yang baik, artinya layak digunakan secara finasial karena keuntungan yang positif dan nilai efektifitas ekonominya lebih dari satu.

Tabel 7 menunjukkan bahwa perlakuan B (100 kg urea ha- ${ }^{-1}, 200{\mathrm{~kg} \mathrm{SP} 36 \mathrm{ha}^{-1}, 100 \mathrm{~kg} \mathrm{KCl} \mathrm{ha}}^{-1}$ ) memiliki nilai ekonomis yang paling tinggi sebesar 44,19 . Tetapi penggunaan pupuk anorganik secara terus menerus dapat mengakibatkan kerusakan lingkungan dan menyebabkan tanah menjadi mudah erosi.

Perlakuan yang efektif digunakan adalah perlakuan F 5.000kg Organonitrofos ha ${ }^{-1}$, karena nilai index rasio pupuk sebesar 7,26 baik pupuk subsidi maupun non subsidi dan yang paling penting ramah lingkungan. Hal ini berarti bahwa menunjukkan bahwa nilai index rasio perlakuan F (5.000kg Organonitrofos ha $^{-1}$ ) lebih besar dari satu, artinya usahatani mentimun menggunakan pupuk tunggal Organonitrofos menguntungkan untuk diusahakan.

Dengan demikian hasil yang diperoleh untuk usahatani dalam skala besar yang lebih direkomendasikan menggunakan perlakuan $\mathrm{F}(5.000 \mathrm{~kg}$ Organonitrofos $\mathrm{ha}^{-1}$ ), sebagai alternatif pengganti pupuk anorganik dan mengefisienkan penggunaan pupuk anorganik dalam budidaya mentimun yang paling menguntungkan untuk pupuk subsidi maupun non-subsidi. Jika dihubungkan dengan RAE dapat dikatakan menguntungkan dari sisi agronomis dan ekonomis. Selain itu dengan pupuk Organonitrofos ini mampu memperbaiki kesuburan tanah sehingga mampu menciptakan pertanian yang berkelanjutan.

Tabel 6. Hasil perhitungan Relative Agronomic Effectiveness (RAE) pada bobot buah segar, bobot kering tanaman dan bobot kering buah mentimun dan total biomass.

\begin{tabular}{lcccc}
\hline $\begin{array}{c}\text { Perlakuan }\left(\mathrm{kg} \mathrm{ha}^{-1}\right) \\
\text { Urea }- \text { SP36- KCl -Organonitrofos }\end{array}$ & $\begin{array}{c}\text { Bobot buah } \\
\text { segar } \\
(\%)\end{array}$ & $\begin{array}{c}\text { Bobot kering } \\
\text { tanaman } \\
(\%)\end{array}$ & $\begin{array}{c}\text { Bobot kering } \\
\text { buah } \\
(\%)\end{array}$ & $\begin{array}{c}\text { Total biomass } \\
(\%)\end{array}$ \\
\hline A $(0-0-0-0)$ & - & - & - & - \\
B $(100-200-100-0)$ & 100 & 100 & 100 & 100 \\
C $(75-150-75-1.000)$ & $-0,02$ & 110,20 & 100 & 108,93 \\
D $(50-100-50-2.000)$ & $-109,11$ & 40,82 & 100 & 48,21 \\
E $(25-50-25-3.000)$ & 30,23 & 14,29 & 114,29 & 26,79 \\
F $(0-0-0-5.000)$ & 196,23 & 91,84 & 71,43 & 89,29 \\
\hline
\end{tabular}

Keterangan : jika nilai RAE $\geq 100 \%$ maka pupuk yang diuji bersifat efektif dibanding perlakuan pupuk standar rekomendasi.

Tabel 7. Index rasio pupuk Organonitrofos dan kombinasinya dengan pupuk anorganik.

\begin{tabular}{lccc}
\hline \multicolumn{1}{c}{ Perlakuan $\left(\mathrm{kg} \mathrm{ha}^{-1}\right)$} & \multicolumn{2}{c}{ Pupuk non - subsidi } & Pupuk subsidi \\
Urea - SP36- KCl - Organonitrofos & Eceran & Grosir & \\
\hline A $(0-0-0-0)$ & 0 & 0 & 0 \\
B $(100-200-100-0)$ & 12,59 & 23,76 & 44,19 \\
C $(75-150-75-1.000)$ & 10,76 & 13,24 & 17,20 \\
D $(50-100-50-2.500)$ & 6,07 & 6,66 & 7,37 \\
E $(25-50-25-3.000)$ & 8,04 & 8,41 & 8,81 \\
F $(0-0-0-5.000)$ & 7,26 & 7,26 & 7,26 \\
\hline
\end{tabular}

Keterangan : Jika nilai yang dihasilkan $>1$, maka pupuk yang diuji memiliki nilai ekonomis yang baik.

\section{KESIMPULAN}

Berdasarkan hasil analisis dan pembahasan dalam penelitian ini, maka dapat disimpulkan sebagai berikut: (1) Pemberian pupuk Organonitrofos dan kombinasinya dengan pupuk anorganik pada dosis $75 \mathrm{~kg}$ urea ha-1, $150 \mathrm{~kg}$ SP-36 ha-1, $75 \mathrm{~kg} \mathrm{KCl} \mathrm{ha}{ }^{-1}, 1.000 \mathrm{~kg}$ Organonitrofos ha ${ }^{-1}$ dapat meningkatkan serapan hara $\mathrm{N}, \mathrm{P}, \mathrm{K}$, namun tidak berpengaruh terhadap pertumbuhan dan produksi mentimun pada musim tanam kedua. (2) 
Pupuk tunggal Organonitrofos dosis $5.000 \mathrm{~kg} \mathrm{ha}^{-1}$ lebih direkomendasikan untuk petani mentimun, karena merupakan dosis paling efektif secara agronomis (Relative Agronomic Effektiviness) maupun secara ekonomis dan dapat menciptakan pertanian yang berkelanjutan.

\section{DAFTAR PUSTAKA}

Agromedia. 2010. Kondisi Kelangkaan Pupuk Subsidi di Pasaran. Diakses pada 28 Mei 2013 http:// www.agromedia.go.id. Indonesia.

Amin, K.S. dan B.A. Ullasa. 1981. Effect of thiophanate on epidemic development of antracnose and yield of watermelon. Phytopathology. 71(1):20-22.

BPS. 2013. Produksi Tanaman Mentimun Di Indonesia 2011-2012. Sebuah artikel. http://bps.go.id. Diakses pada tanggal 26 Mei 2013.

Balai Penelitian Tanah. 2005. Petunjuk Teknis: Analisis Kimia Tanah, Tanaman, Air dan Pupuk. Departemen Pertanian. Bogor. $136 \mathrm{Hlm}$.

Dwijoseputro. 1980. Pengantar Fisiologi Tumbuhan. Gramedia. Jakarta. $200 \mathrm{Hlm}$.

Gardner, F.P., R.B. Pearce and R.L. Mitchell. 1991. Physiology of Crop Plants. Terjemahan: Fisiologi Tanaman Budidaya. Penerjemah : Herawati Susilo. Pendamping : Subiyanto. Universitas Indonesia Press. Jakarta. 327 pp.

Machay, A. D., J. K. Syers and P. E. H. Gregg. 1984. Ability of Chemical Extraction Procedures to Assess the Agronomic Effectiveness of Phosphate Rock Materials. New Zealand Journal of Agricultural Research 27: 219-230.

Nugroho, S.G., Dermiyati, J. Lumbanraja, S. Triyono, and H. Ismono. 2012. Optimum Ratio of Fresh Manure and Grain of Phosphate Rock Mixture in a Formulated Compost for Organomieral NP Fertilizer. J. Trop Soil 17 (2) : 121-128.

Permentan. 2011. Persyaratan Teknis Minimal Pupuk Organik Padat. No: 70/Permentan/SR.140/10/ 2011. Jakarta. $71 \mathrm{Hlm}$.

Saeri, M. dan Suwono. 2012. Kajian Efektivitas Pupuk NPK Pelangi Dalam Upaya Peningkatan Hasil dan Pendapatan Petani Jagung Dilahan Kering Tuban. Tuban, Jawa Timur. 9 Hlm.
Salam, A. K. 2012. Ilmu Tanah Fundamental. Global Madani Press. Bandar Lampung. $362 \mathrm{Hlm}$.

Simanungkalit, R. D. M. 2006. Aplikasi Pupuk Hayati dan Pupuk Kimia: Suatu Pendekatan Terpadu. Balai Penelitian Bioteknologi Pangan. Bogor. Buletin AgroBio 4(2): 56-61.

Sopiyani. 2014. Pengaruh Pupuk Organonitrofos dan Kombinasinya Dengan Pupuk Kimia Terhadap Pertumbuhan, Produksi Serta Serapan Hara Tanaman Cabai Merah Keriting (Capsicum annuum L.) Pada Tanah Ultisol Gedung Meneng. Skripsi. Universitas Lampung. Bandarlampung. Hal 38- 40.

Sri Adiningsih dan Mulyadi. 1993. Alternatif teknik rehabilitasi dan pemanfaatan lahan alang-alang. Dalam S. Sukmana, Suwardjo, Sri Adiningsih, H. Subagjo, H. Suhardjo, Y. Prawirasumantri (Ed.). Pemanfaatan lahan alang-alang untuk usaha tani berkelanjutan. Prosiding. Seminar Lahan Alang-alang, Bogor, Desember 1992. Pusat Penelitian Tanah dan Agroklimat. Badan Litbang Pertanian. Hal 29"50.

Subagyo, H., N. Suharta, dan A.B. Siswanto. 2004. Tanah-tanah pertanian di Indonesia. Dalam A. Adimihardja, L.I. Amien, F. Agus, D. Djaenudin (Ed.). Sumberdaya Lahan Indonesia dan Pengelolaannya. Pusat Penelitian dan Pengembangan Tanah dan Agroklimat, Bogor. Hal. 21"66.

Sunarjono, H. 2004. Bertanam 30 Jenis Sayuran. Penebar Swadaya. Jakarta. $58 \mathrm{Hlm}$.

Sutedjo, M. M. 1994. Pupuk dan Cara Pemupukan. Rineka Cipta, Jakarta. $173 \mathrm{Hlm}$.

Syukur, A. 2005. Penyerapan Posfor oleh Tanaman Jagung di Tanah Pasir Pantai Bugel dalam Kaitannya dengan Tingkat Frekuensi Penyiraman dan Pemberian Bahan Organik. J. Ilmu Tanah Dan Lingkungan 5 (2) : 20-26.

Tresya, M.D. 2012. Pengaruh Pemberian Pupuk KCl Terhdap Pertumbuhan dan Produksi Tanaman Mentimun (Cucumis sativus L.). Universitas Gorontalo. Gorontalo. Hal 19. 
Wargiono, J. 2003. Pemupukan NPK dan Sistem Tanam Ubi Kayu pada Tanah Ultisol. Balai Penelitian Tanaman Kacang-Kacangan dan Umbi-Umbian. Lampung. Penelitian Pertanian Tanaman Pangan 22 (2): 116-117.

Yupitasari, M. 2013. Pengaruh Pupuk Organonitrofos dan Kombinasinya dengan Pupuk Kimia terhadap Pertumbuhan, Serapan Hara dan Produksi Tanaman Tomat (Lycopersicom esculentum) Pada Musim Tanam Kedua. Skripsi. Universitas Lampung Bandar Lampung. $92 \mathrm{Hlm}$.
Zulyana, U. 2011. Respon Ketimun (Cucumis sativus L.) terhadap Pemberian Kombonasi Dosis dan Macam Bentuk Kotoran Sapi di Getasan. Skripsi. Universitas Sebelas Maret. Surakarta. 69 Hlm. 